\title{
KETAHANAN PANGAN RUMAH TANGGA DAN AKSES PANGAN SEBAGAI FAKTOR RISIKO TERJADINYA DIABETES MELITUS TIPE 2
}

\author{
Nor Eka Noviani ${ }^{{ }^{*} \text {, Istiti Kandarina }}{ }^{2}$, Fatma Z Nisa ${ }^{3}$ \\ 1. Program Studi S1 Gizi Fakultas Ilmu Kesehatan Universitas 'Aisyiyah Yogyakarta, Yogyakarta- \\ Indonesia \\ 2. Departemen Biostatistik Epidemiologi Kesehatan populasi FK UGM, Yogyakarta-Indonesia \\ 3. Departemen Gizi dan Kesehatan FK UGM, Yogyakarta-Indonesia
}

*Korespondensi: Nor Eka Noviani | STIKes Mitra Keluarga | norekanoviani27@gmail.com

\begin{abstract}
Abstrak
Pendahuluan: Tidak tahan pangan adalah situasi ketika seseorang tidak memiliki akses secara fisik, sosial dan ekonomi untuk memenuhi pangan yang cukup, beragam, aman dan bergizi sesuai kebutuhan untuk hidup sehat dan aktif, yang selanjutnya tidak tahan pangan berhubungan dengan penyakit kronis, termasuk diabetes melitus tipe 2 (DM2). Tujuan penelitian ini untuk mengetahui apakah tidak tahan pangan dan rendahnya akses pangan merupakan faktor risiko terjadinya DM2 di Kabupaten Kulon Progo.

Metode: Jenis penelitian ini adalah analitik dengan desain kasus dan kontrol. Kasus adalah 63 penyandang DM2 yang terdaftar di 4 kecamatan di Kulon Progo. Sedangkan kontrol adalah 63 responden bukan penyandang DM2. Penentuan sampel menggunakan metode purposive dengan penyetaran umur, jenis kelamin dan tempat tinggal. Ketahanan pangan diukur dengan 10 pertanyaan di kuesioner Radimer/Cornel, sedangkan akses pangan dihitung dengan pangsa pengeluaran pangan (PPP) dari kuesioner ekonomi nasional. Variabel lain adalah pendidikan, riwayat keluarga dan pendapatan keluarga.

Hasil: Sebagian responden menempuh pendidikan $>9$ tahun (50,79\% di kelompok kasus dan 60,31\% kelompok kontrol). Mereka juga memiliki penghasilan keluarga yang tinggi (>3,2 juta) di kedua kelompok (kasus=65,07;kontrol=74,60\%). Riwayat keluarga positif 52,38 di kelompok kasus. Berdasarkan uji $\mathrm{x}^{2}$, riwayat keluarga memiliki hubungan yang bermakna dengan DM2 ( $<<0,05 ; \mathrm{OR}=10,45 ; 95 \% \mathrm{CI}=3,70-33,32)$. Tidak tahan pangan lebih banyak terjadi pada kelompok kontrol $(79,36 \%)$ daripada kasus $(66,67 \%)$. Total pengeluaran pangan dan bukan pangan di kelompok kasus lebih tinggi daripada kelompok kontrol. Prosentase PPP tinggi (>60\%) sebanyak $84,13 \%$ di kasus dan 77,78\% di kontrol. Mc Nemar menunjukkan tidak tahan pangan dan akses pangan secara statistik tidak bermakna $(\mathrm{p}>0,05)$. Berdasarkan regresi logistik, riwayat keluarga memiliki hubungan paling kuat berkembangnya DM2 ( $\mathrm{p}<0,05 ; \mathrm{OR}=11,95)$, tidak tahan pangan memiliki nilai $\mathrm{p}=0,034$ dan $\mathrm{OR}=0,37$.

Kesimpulan: Tidak tahan pangan dan akses pangan bukan merupakan faktor risiko DM2, akan tetapi riwayat keluarga memiliki faktor risiko timbulnya DM2 di Kulon Progo tahun 2015.
\end{abstract}

Kata Kunci: Tidak tahan pangan, Diabetes melitus, Akses pangan, Riwayat keluarga.

Diterima 12 Mei 2019; Accepted 30 Juni 2019

\section{PENDAHULUAN}

Pangan merupakan kebutuhan dasar manusia, selain kebutuhan akan air, rasa aman, tempat tinggal, pendidikan dan kesehatan. Ketahanan pangan masuk dalam daftar sosial determinan kesehatan yang menjadi perhatian kesehatan masyarakat sejak lama. Menurut Peraturan Pemerintah Republik Indonesia Nomor 17 tahun 2015, ketahanan pangan adalah kondisi terpenuhinya pangan bagi negara sampai dengan perseorangan, yang tercermin dari tersedianya pangan yang cukup, baik jumlah maupun mutunya, aman, beragam, bergizi, merata, dan terjangkau serta tidak bertentangan dengan agama, keyakinan, dan budaya masyarakat, untuk dapat hidup sehat, aktif, dan produktif secara berkelanjutan. Ketika kondisi pangan bagi negara sampai dengan perorangan tidak terpenuhi maka kondisi yang terjadi adalah tidak tahan pangan. Penelitian sebelumnya juga mengungkapkan bahwa rumah tangga yang tidak tahan pangan terjadi ketika akses terhadap makanan yang aman dan cukup itu terbatas, tidak pasti atau tergantung pada pasokan makanan darurat, mencari-cari atau mencuri(Bickel et al., 2000).

Berdasarkan data dari Global Food Security Index (GFSI) pada tahun 2015, selama beberapa tahun terakhir, kondisi ketahanan pangan meningkat di hampir setiap bagian dunia. Kebijakan yang benar, prioritas dan investasi dapat meningkatkan ketahanan pangan secara cepat. Di kawasan Asia dan Pasifik, dasar perekonomian yang kuat mendorong pertumbuhan Gross Domestic Product (GDP) di dalam pasar, dimana skor tersebut naik menjadi $73 \%$. Kunci yang mendorong pertumbuhan perekonomian di kawasan 
ini adalah tingginya angka tabungan dan investasi, pertumbuhan kekuatan kerja dan perkembangan produktivitas pertanian yang lebih tinggi.

Seratus sembilan negara yang terdaftar di dalam GFSI tahun 2015 menempatkan Indonesia pada posisi 74. Data dari Badan Ketahanan Pangan (BKP) tahun 2014, persentase angka tidak tahan pangan di Indonesia meningkat setiap tahun. Pada tahun 2013, 47,02 juta penduduk atau 19,04\% dari seluruh penduduk di Indonesia mengalami kondisi tidak tahan pangan(Badan Ketahanan Pangan, 2014). Di Provinsi Daerah Istimewa Yogyakarta, prosentase jumlah penduduk tidak tahan pangan sebanyak 35.63\%.

Tidak tahan pangan berhubungan dengan status kesehatan yang buruk, termasuk diabetes melitus tipe 2. Perkembangan diabetes melitus tipe 2 juga dipengaruhi oleh faktor genetik. WHO menyatakan bahwa keturunan pertama individu dengan diabetes melitus tipe 2 berisiko 3 kali lebih besar daripada individu tanpa riwayat keluarga positif diabetes. Meskipun gen memberikan peranan yang besar terhadap perkembangan DM tipe 2, faktor lingkungan juga memberikan kontribusi terjadinya diabetes melitus tipe 2(Fitzgerald et al., 2011).

Peralihan secara epidemiologis dalam hal pola makan, aktivitas fisik dan komposisi tubuh di banyak negara berkembang dengan cepat. Di kawasan Asia seperti Korea, India, Jepang dan negara-negara di Amerika Selatan menyatakan bahwa terjadi perubahan yang cepat dalam kebiasan makan dan komposisi tubuh setelah negara-negara tersebut mencapai kecukukupan makan di tingkat nasional(Lipoeto et al., 2004). Perubahan sosial ekonomi yang cepat dan disertai dengan peningkatan urbanisasi dan kebiasaan makan telah merubah pola makan populasi di kawasan Asia Pasifik. Pengalaman di negara Cina, Jepang dan Korea menunjukkan trend insiden yang lebih tinggi pada penyakit degeneratif kronis seperti obesitas, stroke, kanker dan osteoporosis. Kebiasaan makan juga mengalami perubahan dari pola makan dengan karbohidrat kompleks dari serealia dan rendah lemak menuju pola makan tinggi kalori dengan peningkatan konsumsi produk hewan, lemak dan gula serta penurunan konsumsi makanan pada karbohidrat kompleks(Kosulwat, 2002).

Indonesia juga dihadapkan dengan fenomena transisi kesehatan. Sejak pertengahan dekade 1960an, terjadi peralihan yang luar biasa di dalam perekonomian Indonesia yang merubah struktur sosial demografi dan berpengaruh pada perubahan yang besar pada pola makan di Indonesia (Lipoeto et al., 2004).

Kabupaten Kulon Progo yang berada di Provinsi Daerah Istimewa Yogyakarta memiliki prevalensi diabetes melitus tipe 2 nomor 3, sebesar 2,3\% setelah Kota Yogyakarta dan Kabupaten Sleman(Badan Penelitian dan Pengembangan Kesehatan, 2013). Berdasarkan Survei Terpadu Penyakit (STP) tahun 2014, jumlah kasus diabetes melitus tipe 2 mengalami peningkatan. Tahun 2010 hingga tahun 2012 terjadi peningkatan dari 1979 menjadi 4.191 pasien (Bagian Epidemiologi, 2014).

Visi pembangunan jangka menengah Kabupaten Kulon Progo adalah terwujudnya Kulon Progo yang sehat dan mandiri yang mampu meningkatkan kualitas kesehatan masyarakat, baik sehat jasmani dan rohani(Progo, 2011). Berdasarkan uraian yang telah dijabarkan di atas, peneliti ingin mengetahui lebih jauh tentang kesehatan masyarakat di Kulon Progo, dengan mendalami keterkaitan antara ketahanan pangan dengan diabetes melitus tipe 2 di Kabupaten Kulon Progo.

\section{METODE}

Jenis penelitian ini adalah obeservational dengan rancangan kasus dan kontrol. Kasus adalah individu DM2 yang mendapat perawatan dari puskesmas. Sedangkan kontrol adalah responden yang tidak menyandang diabetes melitus tipe 2. Penelitian ini dilaksanakan di 3 bagian wilayah Kabupaten Kulon Progo. Penelitian dilaksanakan dari bulan September hingga November 2015.

Responden terpilih berada di 4 kecamatan di Kabupaten Kulon Progo, yakni Wates, Sentolo, Kalibawang dan Samigaluh yang mewakili topografi daerah Kulon Progo dari selatan yang berupa dataran rendah, tengah dan utara yang merupakan perbukitan. Pengambilan responden kasus dilakukan dengan mendata kunjungan pasien di 4 puskesmas selama 3 bulan terakhir dan dipilih secara purposive dengan jumlah 63 kasus. Sedangkan 63 kontrol dipilih dengan penyetaraan terhadap umur dan jenis kelamin berdasarkan data di kelurahan tempat tinggal kasus. Dalam pengumpulan data, peneliti dibantu oleh 4 enumeroter sarjana gizi. Penelitian ini juga telah mendapat persetujuan dari Komite Etik Fakultas Kedokteran Universitas Gadjah Mada.

Ketahanan pangan diukur dengan kuesioer Radimer/Cornell hunger and food security yang dikembangkan dari Cornell University (Kendall et al., 1995). Rangkaian kesatuan yang berawal dari 
ketidakpastian dan kecemasan terhadap pemenuhan makanan di tingkat rumah tangga hingga terjadi kelaparan pada anak ketika mereka tidak memiliki cukup makanan (Kendall et al., 1995). Pengukuran ketahanan pangan secara tidak langsung menggunakan pangsa pengeluaran pangan di dalam rumah tangga. Akses pangan adalah kemampuan untuk dapat memenuhi pengeluaran (konsumsi) pangan yang cukup sesuai kebutuhan dibandingkan tingkat pengeluaran (konsumsi) keseluruhan pada pangan dan bukan pangan. Akses pangan diukur dengan Pangsa Pengeluaran Pangan (PPP). Perhitungan PPP dengan rumus sebagai berikut:

PPP $\quad=\frac{P P}{T P} \times 100 \%$
PPP $\quad=$ pangsa pengeluaran pangan
PP $\quad=$ pengeluaran pangan rumah tangga untuk kelompok pangan
TP $\quad=$ total pengeluaran rumah tangga untuk kelompok pangan dan non pangan

Hasil persentase perhitungan PPP, kemudian dikategorikan dengan ketentuan sebagai berikut:

Tinggi $=$ kategori $\mathrm{PPP} \leq 60 \%$ pengeluaran total

Rendah $=$ kategori PPP $>60 \%$ pengeluaran total

Pangsa pengeluaran pangan layak dijadikan indikator ketahanan pangan karena mempunyai hubungan yang erat dengan berbagai ukuran ketahanan pangan seperti tingkat konsumsi, keanekaragaman pangan, pendapatan serta memiliki ciri dapat diukur dengan angka, cukup sderhana untuk memperoleh dan menafsirkannya, obyektif dan responsif terhadap perubahan-perubahan akibat adanya perubahan kondisi perekonomian, kebijakan dan program pembangunan. Batasan untuk akses pangan adalah $60 \%$ dari total pengeluaran(Maxwell, 1992).

Pangsa pengeluaran pangan diukur dengan menggunakan kuesioner terstruktur dari Badan Pusat Statistik (BPS). Kuesioner tersebut adalah kuesioner konsumsi rumah tangga yang dicakup di dalam Survei Sosial Ekonomi Nasional (Susenas) yang dibedakan atas konsumsi makanan dan bukan makanan tanpa memperhatikan asal barang baik berasal dari pembelian, produksi sendiri maupun pemberian. Pengeluaran rumah tangga terbatas pada pengeluaran untuk kebutuhan rumah tangga saja, tidak termasuk pengeluaran untuk keperluan usaha atau yang diberikan kepada pihak lain. Pengeluaran untuk konsumsi makanan dihitung selama seminggu terakhir, sedangkan konsumsi bukan makanan selama sebulan dan 12 bulan terakhir. Pengeluaran konsumsi makanan maupun bukan makanan selanjutnya dikonversikan ke dalam pengeluaran rata-rata sebulan.

\section{HASIL}

Tabel 1 mendeskripsikan gambaran responden kelompok kasus dan kontrol. Jumlah responden dalam penelitian ini adalah 126, dimana dua pertiganya adalah perempuan. Usia rata-rata responden kelompok kasus dan kontrol adalah 49,8 dan 49,5 tahun. Sebanyak 63,49\% di kelompok kasus dan 60,32\% di kelompok kontrol menempuh pendidikan minimal 9 tahun. Banyak responden yang pendapatan keluarganya dibawah 3,2 juta, yakni 73,02\% di kelompok kasus dan 65,08\% di kelompok kontrol. Pada riwayat keluarga, dikelompok kasus sebanyak 52,38\% memiliki faktor keturunan dan sisanya 47,62\% karena faktor bukan keturunan.

Tabel 2 menggambarkan status ketahanan pangan pada responden di Kulon Progo.Banyak responden yang berstatus tidak tahan pangan, baik untuk kelompok kasus, maupun kelompok kontrol, masing-masing $66,67 \%$ dan $79,36 \%$.

Prosentase tahan pangan untuk kasus maupun kontrol masing-masing 33,3\% dan 26,98\% Pada kategori akses pangan, prosentase akses pangan tinggi lebih besar pada kedua kelompok, yaitu 84\%,13 pada kasus dan $77,78 \%$ pada kontrol. Sedangkan pada kategori penyerapan pangan, lebih banyak responden memiliki penyerapan pangan yang tinggi, baik di dalam kelompok kasus maupun kontrol, yakni $69,84 \%$ dan $58,73 \%$.

Analisis multivariat digunakan untuk mengetahui kontribusi semua variabel terhadap ketahanan pangan dengan diabetes melitus tipe 2 dapat dilihat dengan menggunakan model analisis regresi logistik 
(logistic regression). Pertimbangan yang dipakai dalam analisis ini adalah variabel yang dalam analisis bivariat mempunyai nilai $\mathrm{p}<0,25$ yakni ketahanan pangan, akses pangan, dan riwayat keluarga.

Hasil analisis multivariat menunjukkan bahwa riwayat keluarga dan ketahanan pangan tetap bermakna $(\mathrm{p}<0,05)$. Seseorang yang memiliki riwayat keluarga yang menyandang diabetes melitus tipe 2 berisiko terkena diabetes melitus tipe 2 sebesar 11,95 kali bila dibandingkan dengan seseorang yang tidak memiliki riwayat keluarga. Sedangkan ketahanan pangan sendiri dapat menjadi faktor protektif terjdinya diabetes melitus tipe 2. Keberadaan variabel-variabel tersebut memprediksi risiko diabetes sebesar 19\%, sedangkan $79 \%$ disebabkan oleh faktor lain.

Tabel 1. Karakteristik responden kelompok kasus dan kontrol

\begin{tabular}{cccccc}
\hline Variabel & \multirow{2}{*}{ Kasus $(\mathbf{n = 6 3 )}$} & Kontrol $(\mathbf{n = 6 3})$ & $\mathbf{p}$ & OR & \multirow{2}{*}{$\mathbf{9 5 \%} \mathbf{C I}$} \\
\hline Pendidikan, $\geq 9$ tahun, $\mathrm{n}(\%)$ & $40(63,49)$ & $38(60,32)$ & 0,28 & 0,67 & $0,31-1,45$ \\
Pendapatan, <3,2 jt, $\mathrm{n}(\%)$ & $46(73,02)$ & $41(65,08)$ & 0,24 & 0,63 & $0,27-1,46$ \\
Riwayat keluarga, ada, $\mathrm{n} \%$ & $33(52,38)$ & $6(9,52)$ & $0,00^{*}$ & 10,45 & $3,70-33,32$ \\
\hline
\end{tabular}

Keterangan:* signifikan $\mathrm{p}<0,05$

Tabel 2. Status Ketahanan Pangan dan Akses Pangan di Rumah Tangga Kasus dan Kontrol

\begin{tabular}{ccccccc}
\hline Status & \multicolumn{2}{c}{ Kasus } & \multicolumn{2}{c}{ Kontrol } & \multirow{2}{*}{$\mathbf{\text { OR }}$} & $\mathbf{9 5 \%} \mathbf{C I}$ \\
\hline Ketahanan pangan & $\mathbf{N}$ & $\mathbf{\%}$ & $\mathbf{n}$ & $\mathbf{\%}$ & & \\
tidak tahan pangan & 42 & 66,67 & 50 & 79,36 & 0,13 & 0,46 \\
$\quad$ tahan pangan & 21 & 33,3 & 13 & 20,63 & & $0,19-1,12$ \\
$\begin{array}{c}\text { Akses Pangan } \\
\text { Rendah }\end{array}$ & 10 & 15,87 & 14 & 22,22 & 0,36 & 0,66 \\
$\quad$ Tinggi & 53 & 84,13 & 49 & 77,78 & & $0,23-1,77$ \\
\hline
\end{tabular}

Keterangan:* signifikan $\mathrm{p}<0,05$

Tabel 3. Analisis Multivariat

\begin{tabular}{ccccc}
\hline Variabel & SE & P value & OR & 95\% CI \\
\hline Model & & & & \\
Riwayat keluarga & 6,12 & $0,000^{*}$ & 11,95 & $4,38-32,63$ \\
Ketahanan pangan & 0,17 & $0,034^{*}$ & 0,37 & $0,15-0,92$ \\
\hline Deviance (-2 log likelihood) & & 70,48 & & \\
$\mathrm{R}^{2}$ & & 0,193 & & \\
\hline
\end{tabular}

Keterangan:* signifikan $\mathrm{p}<0,05$

\section{PEMBAHASAN}

Banyak responden penyandang diabetes melitus berada pada umur di atas 40 tahun. Penelitian yang dilakukan pada tahun 2012 juga menyatakan bahwa prevalensi diabetes melitus tertinggi pada kelompok 46-60 tahun. Proporsi perempuan penyandang diabetes melius tipe 2 di penelitian tersebut lebih tinggi dari laki-laki.(Ekpenyong et al., 2012) Hal ini sesuai dengan penelitian riset kesehatan dasar, dimana prevalensi diabetes melitus lebih tinggi pada perempuan.(Kesehatan, 2013) Pendidikan yang rendah ( $<9$ tahun) juga berisiko terjadi diabetes melitus sebesar $14 \%$ dibanding responden dengan pendidikan tinggi.(Saydah, 2016) Penelitian yang dilakukan pada tahun 2006 juga menyebutkan bahwa .lingkungan dengan pendapatan rendah memiliki prevalensi lebih besar terkena diabetes daripada lingkungan makmur (Rabi et al., 2006)

Hasil penelitian menunjukkan bahwa banyak responden mengalami tidak tahan pangan baik di kelompok kasus maupun kontrol, dan ketahanan pangan secara signifikan tidak berhubungan dengan terjadinya diabetes melitus tipe 2. Ketidaktahanan pangan dialami oleh kedua kelompok. Pada kelompok kasus, prosentase tidak tahan pangan keluarga sebesar 66,67\%, yang dapat berpengaruh terhadap 
manajemen diabetes pada penyandang DM. Sedangkan pada kelompok kontrol prosentase ketidaktahanan pangan sebesar 79,36\%. Hasil ini berbeda dengan penelitian Gucciardi et al., (2009) yang menyatakan bahwa tidak tahan pangan pada keluarga lebih tinggi pada orang- orang Canada dengan diabetes. Penelitian oleh menyatakan bahwa penduduk Latin dewasa yang mengalami tidak tahan pangan tingkat berat berisiko 3,3 kali untuk terkena diabetes melitus tipe 2 daripada penduduk yang tahan pangan atau tidak tahan pangan tingkat ringan setelah mengontrol umur, status pekerjaan, akulturasi, lingkar pinggang dan karakteristik gaya hidup(Fitzgerald et al., 2011). Penelitian lain juga menyatakan bahwa tidak tahan pangan merupakan faktor risiko terjadinya diabetes(Seligman et al., 2007). Hal ini disebabkan penduduk dewasa yang mengalami tidak tahan pangan akan meningkatan konsumsi pangan dengan alternatif makanan yang lebih murah, tidak bergizi dan tinggi kalori. Oleh karena itu, hal ini akan memainkan peranan penting terjadinya diabetes melitus tipe 2 pada rumah tangga tidak tahan pangan.

Pada kelompok kasus, responden penyandang diabetes melitus tipe 2 juga menghadapi tidak tahan pangan di dalam keluarga. Kondisi tersebut sesuai dengan penelitian lain dimana, pasien diabetes melitus tipe 2 yang datang ke klinik mengalami tidak tahan pangan yang dapat menghambat manajemen diabetes(Cheng et al., 2013). Hal ini disebabkan penyandang diabetes yang mengalami tidak tahan pangan mungkin akan mengurangi konsumsi jumlah dan kualitas makanan karena masalah biaya dan akan melakukan suatu kompensasi dengan mengurangi jumlah makanan selama periode shortage (kekurangan makanan) dan mengkonsumsi makanan yang lebih ketika bahan pangan tersedia. Selain itu, asupan makanan yang murah, memiliki kepadatan energi yang tinggi yang semuanya dapat membahayakan pengontrolan gula. Responden dewasa yang tidak tahan pangan dengan diabetes menunjukkan karakter manajemen diabetes yang buruk, termasuk memburuknya diabetes dan kontrol glukosa serta hipoglikemia. Penyandang diabetes melitus yang memiliki beban terhadap manajemen dietnya akan menghadapi pengeluaran biaya yang lebih tinggi untuk pengobatan daripada penyandang lain dengan penyakit kronis lain.

Pada kelompok kasus penyandang DM2 di Kulon Progo, mereka telah mendapatkan konsultasi dari ahli gizi puskesmas, sehingga merekamengubah pola makan dari nasi menjadi growol. Pemilihan makanan pokok, khususnya growol sebagai panga lokal adalah alternatif yang paling baik ketika anggaran terbatas. Growol adalah makanan lokal yang mengandung bakteri asam laktat, sehingga berpotensi sebagai makanan yang mengandung probiotik.

Ketidaktahanan pangan juga diketahui menyebabkan gejala kecemasan, deperesi dan kelelahan serta mengakibatkan kurangnya kontrol terhdap diabetes (Boulé et al., 2003).Kuesioner Radimer Cornel berisi kecemasan atas ketidakpastian terhadap pemenuhan makanan di tingkat rumah tangga. Berdasarkan penelitian di Kulon Progo tidak tahan pangan karena kekhawatiran tidak terpenuhinya pangan menjadi sebuah gambaran bahwa tidak tahan pangan di dalam keluarga menyebabkan kecemasan dan kekhawatiran. Berdasarkan penelitian, orang- orang dewasa yang tidak memiliki uang yang cukup untuk membeli makanan memiliki prosentase $40 \%$ lebih buruk dalam mengontrol kadar glukosa daripada mereka yang secara finansial lebih tahan pangan di populasi negara kaya (Olson, 1999).

Pengeluaran pangan merupakan indikator ketahanan pangan dalam menilai akses pangan. Penilaian akses pangan digunakan untuk membandingkan daya beli pangan dan non pangan (jasa) dalam pengeluaran rumah tangga selama 1 minggu untuk pangan dan 1 bulan dan 12 bulan untuk non pangan. Penelitian menunjukkan bahwa sebagian besar responden termasuk kategori akses pangan tinggi, dan lebih banyak dialami oleh kelompok kasus. Penelitian ini berbeda dengan penelitian yang dilakukan oleh yang menyatakan bahwa responden yang mengalami diabetes melitus tipe 2 akan berhadapan dengan tidak tahan pangan, dimana responden akan berusaha untuk mengakomodasi makanan sehat meskipun dengan anggaran yang terbatas(Cuesta-Briand et al., 2011). Penelitian lain yang menyatakan bahwa tidak tahan pangan karena rendanya akses pada makanan berisiko 1,447 kali untuk terkena diabetes melitus tipe 2(Rabi et al., 2006).

Berdasarkan hasil uji multivariat, ditemukan bahwa faktor risiko yang berpengaruh paling besar terhadap kejadian diabetes melitus tipe 2 di Kulon Progo adalah riwayat keluarga. Diabetes melitus tipe 2 menunjukkan pengaruh hubungan keluarga yang kuat. Bagi mayoritas penyandang diabetes melitus tipe 2, tidak ada pola gen yang lengkap yang berpengaruh terhadap perkembangan diabetes melitus tipe 2 . Patofisiologi berkembangnya diabetes melitus tipe 2 cukup kompleks dan sulit dipahami. Banyak hormon, seperti agen pemberi isyarat yang mempengaruhi metabolisme energi, dilepaskan dari adiposa (seperti 
leptin) dan dari sel kekebalan tubuh (seperti faktor nekrosis tumor- $\alpha$ ). Diabetes melitus tipe 2 dan obesitas dipengaruhi oleh interaksi yang kuat dari gen dan lingkungan sepanjang waktu. Beberapa kerusakan single gen yang ditemukan berpengaruh pada kejadian tersebut, namun pada banyak kasus ada kontribusi yang bersifat polygenic. Faktor gen, termasuk diabetes dan obesitas tidak dapat diubah, namun faktor lingkungan, khususnya kebiasaan makan dan olahraga dapat diubah. Orang orang yang memiliki berat badan lebih yang melakukan aktivitas cukup dan teratur akan menurunkan risiko terjadinya diabetes(Romao \& Roth, 2008).

Ketahanan pangan juga menilai rumah tangga yang tidak mampu mencukupi kebutuhan pangannya. Konsep ini berhubungan dengan ketidakcukupan pangan yang selanjutnya berkaitan dengan kelaparan, sensasi fisik yang disebabkan kekurangan pangan dan kekurangan asupan makanan karena kurangnya sumberdaya finansial. Mereka yang melaporkan tidak memiliki makanan yang cukup untuk dimakan atau mereka yang mengurangi ukuran makanan atau memotong jadwal makannya karena alasan keuangan dianggap sebagai kekurangan pangan. Meskipun pembatas energi pada penanganan diabetes melitus tipe 2, namun ketidakcukupan pangan dapat mempengaruhi kemampuan untuk mencukupi makanan yang bergizi. Ketidakcukupan pangan berhubungan dengan buruknya kualitas diet, termasuk rendahnya konsumsi buah dan sayur serta rendahnya asupan nutrisi esensial yang lain(Nelson et al., 2001).

Dari model 4, tampak bahwa ketahanan pangan merupakan faktor protektif timbulnya diabetes melitus tipe 2. Hal ini disebabkan faktor genetic memiliki pengaruh yang sangat kuat. Tidak tahan pangan di dalam keluarga tidak menjadi faktor risiko. Dari model-model tersebut dapat digambarkan bahwa tidak tahan pangan terhadap berkembangnya diabetes melius tipe 2 memiliki risiko yang kecil. Kondisi tidak tahan pangan yang berdampak pada timbulnya diabetes melitus bersifat kompleks dan saling berkaitan.

Berdasarkan penelitian di Kulon Progo, 67\% persen responden adalah responden dengan lama penyakit $>1$ tahun yang telah memperoleh konsultasi gizi dan telah merubah cara makannya. Mungkin, tidak tahan pangan keluarga sebagai dampak dari penyakit kronis tersebut. Oleh karena itu, perlu penelitian yang sangat spesifik tentang ketahanan pangan. Oleh karena itu, perlu penelitian yang mendalam dan terintegrasi untuk mengetahui apakah tidak tahan pangan di dalam keluarga dapat meningkatkan risiko timbulnya diabetes melitus dengan melibatkan berbagai faktor seperti biologi, perilaku dan lingkungan dengan definisi dan metodologi yang sesuai.

\section{KESIMPULAN}

Secara keseluruhan Status ketahanan pangan rumah tangga bukan faktor risiko terjadinya diabetes melitus tipe 2, tetapi banyak rumah tangga yang mengalami tidak tahan pangan serta memiliki akses pangan tinggi. Faktor risiko yang paling dominan terhadap berkembangnya diabetes melitus tipe 2 di Kabupaten Kulon Progo adalah adanya riwayat keluarga.

Rumah tangga yang tidak tahan pangan diharapkan mampu mengatur keuangan dengan baik dalam memenuhi kebutuhan makanan seperti memilih makanan lokal yang sehat, murah dan bernilai budaya sebagai alternatif sumber karbohidrat, memilih buah dan sayur berdasarkan musim dan langsung dari petani.

\section{REFERENSI}

Badan Ketahanan Pangan, K. P. (2014). Statistik Ketahanan Pangan Tahun 2013. Badan Penelitian dan Pengembangan Kesehatan. (2013). Riskesdas dalam Angka Provinsi

\section{Daerah Istimewa}

Yogyakarta Tahun 2013. Jakarta. https://doi.org/ISBN 978-602-235-534-2

Bagian Epidemiologi. (2014). Laporan Survey Terpadu Penyakit 2014. Kulon Progo.

Bickel, G., Nord, M., Price, C., Hamilton, W., \& Cook, J. (2000). Guide to Measuring Household Food Security Revised 2000. Agriculture, 1-76. Retrieved from http://scholar.google.com/scholar?hl=en\&btnG=Search\&q=intitle:Guide+to+Measuring+Household+F ood+Security+Rev ised+2000\#0

Boulé, N. G., Tremblay, a, Gonzalez- Barranco, J., Aguilar-Salinas, C. a, Lopez-Alvarenga, J. C., Després, J. P., ... Rios-Torres, J. M. (2003). Insulin resistance and abdominal adiposity in young men with documented malnutrition during the first year of life. International Journal of Obesity and Related Metabolic Disorders, 27(5), 598-604. https://doi.org/10.1038/sj.ijo.0802288

Cheng, S., Kamano, J., Kirui, N. K., Manuthu, E., Buckwalter, V., Ouma, K., \& Pastakia, S. D. (2013). 
Prevalence of food insecurity in patients with diabetes in western Kenya. Diabetic Medicine, 30(6), 215-223. https://doi.org/10.1111/dme.12174

Cuesta-Briand, B., Saggers, S., \& McManus, A. (2011). "You get the quickest and the cheapest stuff you can": Food security issues among low-income earners living with diabetes. Australasian Medical Journal, 4(12), 683-691. https://doi.org/10.4066/AMJ.2011.1104

Ekpenyong, C. E., Akpan, U. P., Ibu, J. O., \& Nyebuk, D. E. (2012). Gender and age specific prevalence and associated risk factors of type 2 diabetes mellitus in Uyo metropolis, South Eastern Nigeria. Diabetologia Croatica, 41(1), 17-28.

Fitzgerald, N., Hromi-Fiedler, A., Segura- Pérez, S., Pérez-Escamilla, R. (2011). Food Insecurity is Related to Increased Risk of Type 2 Diabetes Among Latinas. Ethn Dis., 21(1), 328-334.

Kendall, A V. V. E., Yd, M. O. A, \& Frohgillo, E. A. (1995). Validation of the Radimer / Cornell Measures of Hunger and Food Insecurity. The Journal of Nutrition, 125(January), 2793-2801.

Kesehatan, B. P. dan P. (2013). Laporan Riset Kesehatan Dasar 2013. Jakarta: Balai Penelitian dan Pengembangan Kesehatan Republik Indonesia.

Kosulwat, V. (2002). The nutrition and health transition in Thailand. Public Health Nutrition, 5(1A), 183189. https://doi.org/10.1079/PHN2001292

Lipoeto, N. I., Wattanapenpaiboon, N., Malik, A., \& Wahlqvist, M. L. (2004). Nutrition transition in west Sumatra, Indonesia. Asia Pacific Journal of Clinical Nutrition, 13(3), 312-316.

Maxwell, S. F. T. R. (1992). Household Food Security: Concepts, Indicators, Measurements.

Nelson, K., Cunningham, W., Andersen, R., Harrison, G., \& Gelberg, L. (2001). Is food insufficiency associated with health status and health care utilization among adults with diabetes? Journal of General Internal Medicine, 16(6), 404-411. https://doi.org/10.1046/j.1525-1497.2001.016006404.x

Olson, C. M. (1999). Symposium: Advances in Measuring Food Insecurity and Hunger in the U.S. Introduction. The Journal of Nutrition, 129(2S Suppl), 504S-505S. https://doi.org/0022-3166/99

Progo, P. D. K. K. (2011). Perubahan Rencana Strategis Inspektorat Daerah Kabupaten Kulon Progo Tahun 2011-2016. Kulon Progo.

Rabi, D. M., Edwards, A. L., Southern, D. a, Svenson, L. W., Sargious, P. M., Norton, P., Ghali, W. a. (2006). Association of socio-economic status with diabetes prevalence and utilization of diabetes care services. BMC Health Services Research, 6, 124. https://doi.org/10.1186/1472-6963-6-124

Romao, I., \& Roth, J. (2008). Genetic and Environmental Interactions in Obesity and Type 2 Diabetes. Journal of the American Dietetic Association, 108(4 SUPPL.), 24-28. https://doi.org/10.1016/j.jada.2008.01.02 2

Saydah, S. (2016). Socioeconomic Status and Risk of Diabetes-Related Mortality in the U . S ., 125(3), 377-388.

Seligman, Hilary K., Bindman, Andrew B., Vittinghof,B., Kanaya,AM., Kushel, M. (2007). Food Insecurity is Associated with Diabetes Mellitus : Results from the National Health Examination and Nutrition Examination Survey ( NHANES ) 1999 - 2002. J Gen Intern Me, 22, 1018-1023. 